DOI: $10.1515 /$ pts-2015-0003

\title{
ECCENTRICITY OF SLOW-SPEED SALIENT-POLE GENERATOR: ANALYSIS BASED ON AIR GAP SPECTRUM
}

\author{
M. Griscenko, R. Elmanis-Helmanis \\ Riga Technical University, \\ 1 Kalku Str., Riga LV-1658, LATVIA \\ e-mail: marina.griscenko@rtu.lv
}

\begin{abstract}
The air gap monitoring and fault diagnosis is exemplified for a slowspeed salient-pole generator of hydropower unit. Three types of measurements, namely, with contacting probes, non-contacting sensors and non-invasive sensors are discussed. For the case study non-contacting sensors were applied, with the results demonstrated. In the paper, different methods for evaluation of the results (e.g. using delta value and air gap variation criteria, graphical and spectrum analysis) are described and compared. It has been shown that the spectrum analysis describes changes in the eccentricity better than the criterion method, and is expected to supplement the graphical analysis in the future. Finally, the limitations of the spectrum analysis are formulated, and criteria for this type analysis are proposed.
\end{abstract}

Keywords: air gap, slow-speed generator, air gap spectrum

\section{INTRODUCTION}

The air gap is one of the most important parameters for monitoring the condition of hydropower generation. This parameter measures the space between the spinning rotor and the stationary stator in a hydrogenerator, showing too close position of rotor with respect to the stator. Analysis of the generator air gap also helps to identify unbalanced forces inside, the stator core shifts, the rotor ovality, defects of stator laminations, etc. [1]. Scientists are currently working on mathematical and computer models for generator air gap measurements. This study is focused on the rotor eccentricity and briefly touches the ovality problem in the Spectrum Analysis subsection.

In the study, it is assumed that the information about the generator eccentricity could be obtained from measurements of the air gap [1-3]. In the Results and Discussion section it will be shown that the rotor of generator has an eccentricity and oval shape. The assumption will be proven by spectrum analysis.

The air gap of a slow-speed large hydropower generator with salient poles could be measured in the following ways:

1. in no-load mode with contacting probes [4];

2. with non-contacting capacitive proximity sensors, which allows measuring the air gap in different modes [1,5];

3. with non-invasive measuring systems [6]. 
The method using contacting probes is precise, while can contain human errors [4]. For this method only no-load mode results are available, whereas no data on the dynamic behaviour of the generator could be obtained. The greatest disadvantage of the method is, however, that the hydrogenerator has to be operated manually to run experiments. This takes time, and is therefore not suitable for continuous monitoring. In the Results and Discussion section, comparative results of measurements with contacting probes and with non-contacting sensors are provided to verify the validity of the latter method.

The method with non-contacting capacitive proximity sensors is widely used, being continuously improved. For example, a new method of monitoring the air gap in hydrogenerators using inductive sensors was patented by a team of Swiss engineers [7]. Indeed, the majority of commercially available techniques for detection of eccentricity in salient-pole synchronous machines rely upon the air gap capacitive sensors glued to the stator laminations [6]. Therefore, inductive contacting sensors [5] were used also in this study.

The third method with non-contacting and non-invasive sensors is relatively novel. The direct air gap check is not always possible due to lack of access; therefore, non-contacting measuring systems have a great potential for development. Rozenberg in 2003 [8] described the on-line vibration monitoring system developed by JSC NPO CKTI, whereas the first non-contacting eddy current air gap sensors for hydropower generators had been developed for the given monitoring system already by 2002. Meanwhile, Chelvan (2005) in the thesis [6] stated that most of the commercially available eccentricity detection schemes for synchronous machines are still invasive in nature, and suggested a new model for non-invasive monitoring. Advanced mathematical and numerical models for non-invasive air gap measurements are proposed also in a number of other publications [9-11]. Unfortunately, most of the described ideas are not yet commercially available for case studies.

The first quick step in condition monitoring was obtaining the results for air gap, whereas evaluation of these results and conditions requires more time. The literature review suggests using the following criteria for this purpose:

1. the maximum air gap variation and delta value, or the deviation from average in $\%[2,12]$;

2. the air gap spectrum [2];

3. the air gap for each pole and rotor shape [1].

In our previous study [13], such evaluation was performed based on the delta value defined by the standard (Appendix $F$ in [2]). This is a convenient tool for the evaluation, since the acceptable and the critical limits are clearly defined.

In the Methodology section of the study, the LabVIEW code or the block diagram from spectrum analysis is provided. It will be shown that the spectrum analysis and the graphical one are more useful than the criterion method for measurements with inductive sensors (see the Results and Discussion section). However, the problem is to evaluate the spectrum and the pole diagram. To solve this problem, calculation of vibration spectrum harmonics has been performed, while in the Results and Discussion section the root cause for increase in the air gap harmonics is considered. 
In the mentioned section also the information on vibrations of guide bearings will be provided to consider further the limitations of the study.

This case study refers specifically to a slow-speed hydropower generator and its eccentricity on site, and to the applicability of spectrum analysis proposed previously [13] for mathematical and computer models of the generator under different loads. The objective of this work was to present experimental results of air gap measurements for a hydropower generator and to evaluate its condition by different methods available to date.

\section{METHODOLOGY}

The air gap measurements were performed for a synchronous slow-speed hydropower generator of SV-1510/120-108 type with salient poles. The hydropower generation unit had a propeller-type turbine and the following operating parameters: $U_{\text {nominal }}=13.8 \mathrm{kV}, f=50 \mathrm{~Hz}, \cos \varphi=0.85$.

The rated data of the generator were: $S_{n}=75.3 \mathrm{MVA}, n=55.6 \mathrm{rpm}$. The measurements were carried out in spring and autumn of 2014 to compare the condition of the generator before and after maintenance. The scope of maintenance is given in the Results and Discussion section.

\section{Measurements of the air gap}

The eccentricity was found based on the results of measuring the generator air gap. The measurements were performed with two invasive sensors (sensitivity $0.3 \mathrm{~V} /$ $\mathrm{mm}( \pm 5 \%)$, the operating range 0 - $33 \mathrm{~mm})$ of the air-gap measuring system with LS 120 transducer and ILS 730 signal conditioner [5] mounted on the inner bore of stator. The sensors working on the electric field principle [14] were placed on the upper and lower ends of the stator as illustrated in Fig. 1. The result obtained was the length of air gap (mm).

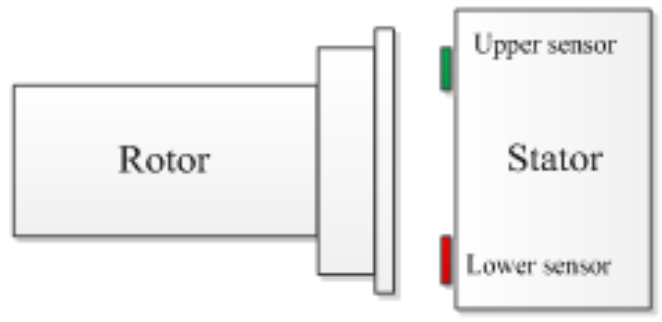

Fig. 1. Placement of inductive invasive sensors.

\section{Generation modes in the experiment}

The experimental design allows analysing the air gap under different modes, since the eccentricity is measured at different operating conditions of the generator, including the runout modes and synchronous compensator (SC) modes with large reactive loads. The specific generation modes are summarised in Table 1. 
Generation modes of the hydropower unit

\begin{tabular}{|l|l|l|}
\hline Mode & Active power, MW & Reactive power, MVAr \\
\hline No-load & 0 & 0 \\
\hline Runout & 0 & 0 \\
\hline Load & $90.5 ; 45 ; 10$ & 0 \\
\hline Load & 90 & $+20 ;-10 ;-20 ;-30 ;-40 ;-50$ \\
\hline $\begin{array}{l}\text { Synchronous com- } \\
\text { pensator mode }\end{array}$ & 0 & $\begin{array}{l}-63 ;-60 ;-50 ;-40 ;-30 ;-20 ;-10 ; 0 ;+10 ; \\
+20\end{array}$ \\
\hline
\end{tabular}

\section{Spectrum analysis}

In our previous study [13] it was stated that for eccentricity evaluation the spectrum analysis should be used. From the frequency response theory it is known that frequency-domain considerations are applicable even when the signals are not periodic. Every measured signal is a time history, and almost any time signal can be converted into its frequency spectrum through the Fourier transform [15]. Thus, in the Results and Discussion section both the air gap spectrum and the vibration one are analysed. For the air gap spectrum analysis the block diagram of measurement reader was adapted as shown in Fig. $2 a$.

For evaluating the geometrical characteristics of rotor poles the LabVIEW code was developed, while capturing the maximum value of rotor pole data was exported to MS excel file directly from the LabVIEW Front Panel graph. A separate block diagram (Fig. $2 b$ ) was used to analyse the spectrum of air gap and to export it to the MS excel file.

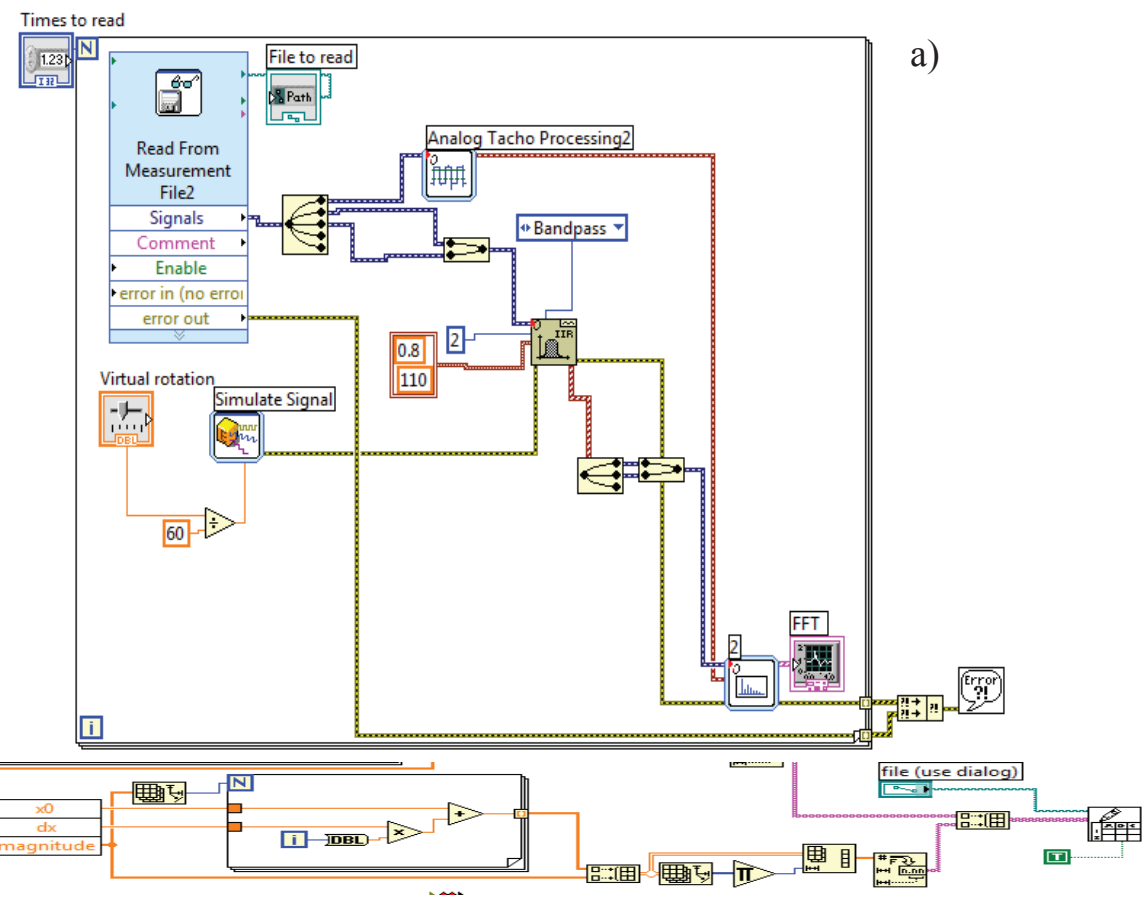

Fig. 2. LabVIEW block diagram: a) for analysing the spectrum of rotor shape; b) for exporting the spectrum to MS excel spread sheet file. 


\section{RESULTS AND DISCUSSION}

The results obtained for the rotor shape were analysed based on the following criteria:

1. The delta value, which is calculated from the maximum and the average air gap values [2].

2. The air gap variation, i.e. the maximum difference between the air gap measured at any point on a single plane and nominal air gap [12].

In addition, Fourier's transformation of the air gap signal and the spectrum analysis were carried out using the block diagram as shown in Fig. $2 a$. It should be noted that the spectrum analysis turned out to be as convenient as the plot diagram, providing at the same time more information about the root cause of uneven air gap.

\section{Measurements of air gap with contacting probes}

For our particular generator the air gap results with using the contacting probe method were obtained before and after the generator maintenance. Specific static measurements were performed by the subcontractor. Delta value was calculated, based on subcontractor measurement report, and the summary of delta value before and after maintenance is provided in Table 2.

Table 2

Air gap values from contacting probe measurements before and after maintenance

\begin{tabular}{|l|l|c|c|l|}
\hline $\begin{array}{l}\text { Probe place- } \\
\text { ment }\end{array}$ & Value & Before & After & $\begin{array}{l}\text { Change in the delta } \\
\text { value }\end{array}$ \\
\hline \multirow{3}{*}{ Top of the rotor } & Maximum & 21.5 & 21.5 & \\
\cline { 2 - 5 } & Average & 19.5 & 19.9 & \\
\cline { 2 - 5 } & Delta & $10.50 \%$ & $8.01 \%$ & Decrease \\
\hline \multirow{3}{*}{$\begin{array}{l}\text { Bottom of the } \\
\text { rotor }\end{array}$} & Maximum & 21.7 & 21.6 & \\
\cline { 2 - 5 } & Average & 19.8 & 20.0 & \\
\cline { 2 - 5 } & Delta & $9.45 \%$ & $7.84 \%$ & Decrease \\
\hline
\end{tabular}

The results of static measurements given in Table 2 provide no information about the eccentricity, ovality, or other characteristics of the generator condition. According to the data of Table 2 , the delta value decreases, while the opposite was observed during dynamic measurements. Nevertheless, this table shows that the delta value is exceeding the acceptance limit of $8 \%$ [2]. The same conclusion about the delta value was drawn from the experiment with non-contacting sensors (see the following subsection).

\section{Evaluation of eccentricity using delta values and air gap variation}

The delta values [2] and air gap variation [12] from dynamic measurements before and after maintenance were collected for the modes listed in Table 1. The summary of delta values is given in Table 3, where one mode for each group from Table 1 was chosen. Contrary to the experimental results with contacting probes, the invasive non-contacting method gives an increase in the delta value at measuring either by upper or by lower sensors. 
Delta values and air gap variation values from invasive non-contacting measurements before and after maintenance

\begin{tabular}{|l|c|c|c|c|}
\hline \multicolumn{5}{|c|}{ Delta values } \\
\hline Mode & Before & After & Before & After \\
\hline No-load & $4 \%$ & $8 \%$ & $5 \%$ & $7 \%$ \\
\hline 45 MW & $3 \%$ & $8 \%$ & $4 \%$ & $8 \%$ \\
\hline Runout & $4 \%$ & $7 \%$ & $3 \%$ & $7 \%$ \\
\hline SK 0MVAr & $5 \%$ & $8 \%$ & $5 \%$ & $8 \%$ \\
\hline \multicolumn{5}{|c|}{ Air gap variation } \\
\hline No-load & $11 \%$ & $11 \%$ & $27 \%$ & $19 \%$ \\
\hline SK 0MVAr & $7 \%$ & $13 \%$ & $24 \%$ & $19 \%$ \\
\hline
\end{tabular}

According to Table 3, the delta values increased almost twice after the maintenance. In compliance with the standard, such a value has not to exceed $8 \%$ [2]. At the same time, the variation up to $20 \%$ is considered acceptable [12]. The rotor balancing and the air gap were expected to be improved after maintenance, while the delta value had to decrease but not to increase. In other modes listed in Table 1 this value is also almost double. Therefore, a deeper analysis was required to find the root cause of such an increase in the delta value.

\section{Evaluation of eccentricity by plotting the air gap values for each pole}

For the diagram, two modes - no-load and SK 0 MVAr - before and after maintenance were chosen, because in these modes the excitation is absent. In other modes, electrical forces and the resulting magnetic field affect additionally the balance of rotor. Magnetic forces also affect the air gap values, but the theory that would link the magnetic force and the air gap is still under development: for example, Babic et.al. (2013) [16] found that correlations between the air gap, magnetic and vibration measurements performed for hydrogenerators are extremely important for detection of magnetic imbalance. In our previous study [13] a relationship was also established for the air gap and electromagnetic force (EMF) values, but the numerical correlation has not yet been obtained. The EMF-related unevenness of air gap [17] is the subject for future research. Meanwhile, avoiding the excitation forces allows for concentration on the mechanical imbalance, disregarding the electrical one.

Figure 3 was composed based on the delta value calculated from the maximum and the average air gap values, showing them in millimetres for each of the 108 rotor poles.

The solid lines in Fig. 3 correspond to the measurements after maintenance, and the dotted ones show the air gap value before maintenance. The results of measurements by upper and lower sensors are shown in Fig. $3 a$ and $3 b$, respectively. In this figure it is seen that the values obtained differ: in the upper sensor case the air gap is $\sim 18 \mathrm{~mm}$, and in the lower sensor case $\sim 22 \mathrm{~mm}$. The rotor diagram shows a decrease in the air gap value, while the difference between the maximum and the minimum values is greater in compliance with the delta value discussed in the previous subsection. For both sensors the solid plot has "sharper" peaks, which explains the cause 
of delta becoming greater after maintenance. The lower sensor diagram has some maxima and minima on the opposite sides of the plot. The peak values suggest that the rotor could have some eccentricity. Since the resulting curve for rotor shape is not circular, we cannot argue with confidence that the eccentricity really exists - the oval shape of rotor might result in the same air gap distortions. The spectrum analysis was used to verify the hypothesis that the rotor has both eccentricity and ovality.
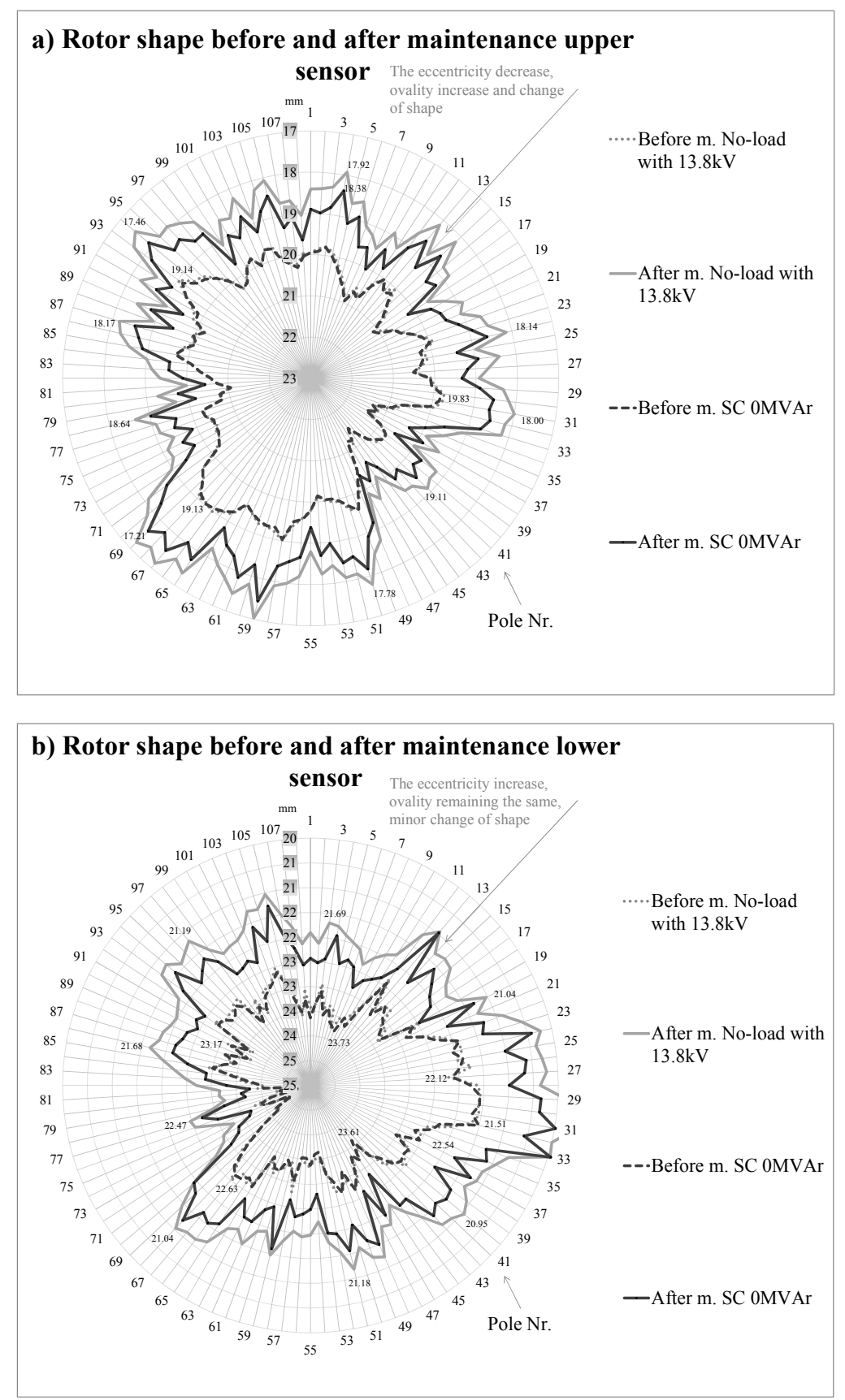

Fig. 3. Rotor shape obtained for each pole profile in the no-load and synchronous compensator modes at zero reactive power: a) for upper sensor; b) for lower sensor. 
From Fig. 3 it is seen that the rotor is extending under different modes. Indeed, both the stator and the rotor in hydro-machines can be quite flexible, with their shape and location affected by centrifugal, thermal, and magnetic forces [1]. The air gap measurements show that the lower end of stator is distorted or off-centrum.

\section{Spectrum analysis of the air gap}

According to the standard [2], more data could be obtained from the spectrum analysis. Therefore, the evaluation method based on spectrum diagram (Fourier analysis) was used to verify the results for air gap. The spectrum results were analysed for each mode given in Table 1 before and after maintenance.

The spectrum for the SC mode with zero reactive power is exemplified in Fig. 4.
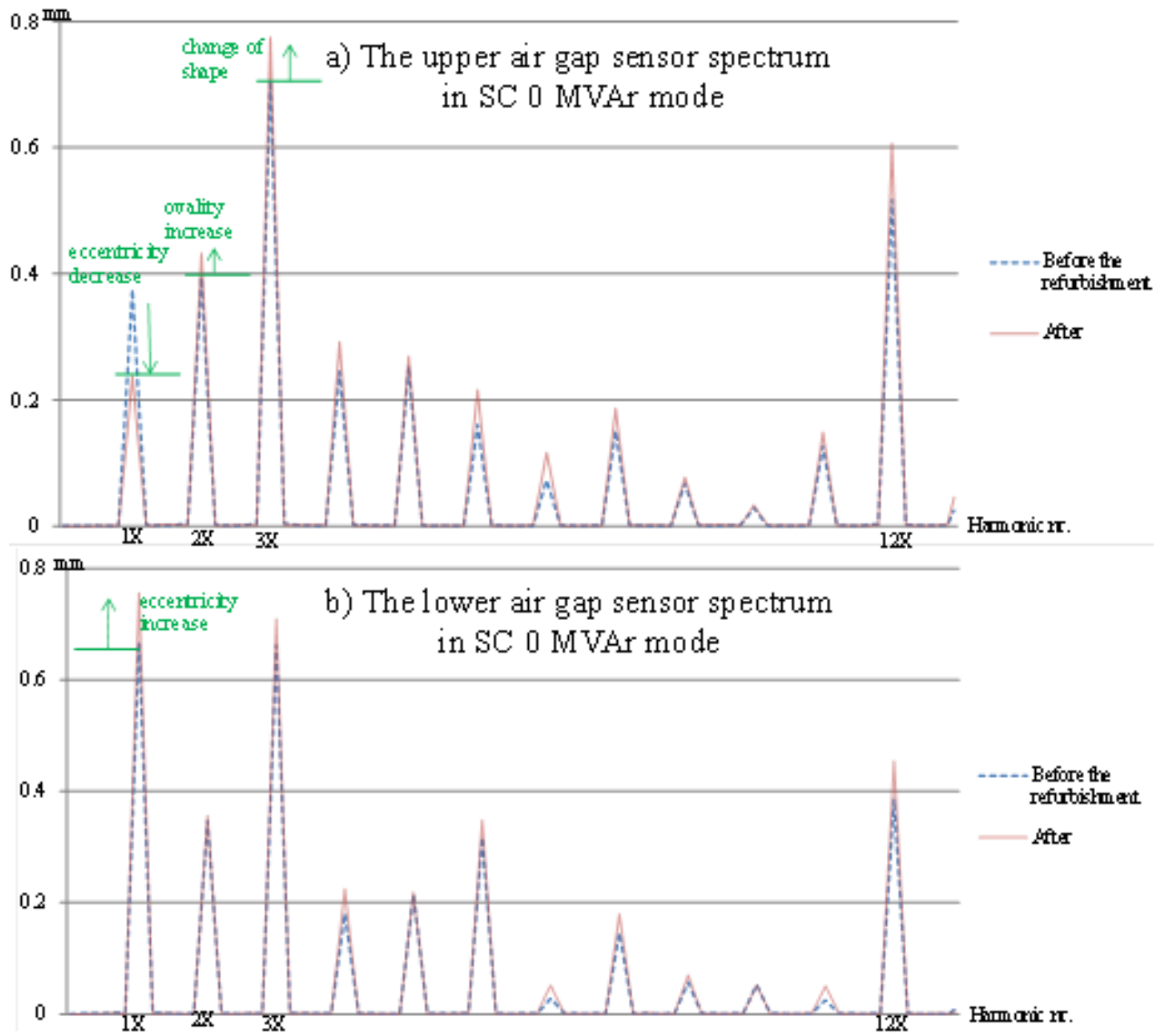

Fig. 4. The order spectrum for air gap measurements with: a) upper sensor b) lower sensor.

The diagram of the spectrum shows that its components - harmonics $1 \mathrm{X}$ and $12 \mathrm{X}$ - increased after maintenance in the lower sensor case. According to the standard for hydropower station maintenance [2], the first harmonic component, called $1 \mathrm{X}$, characterises the eccentricity of the rotor. The second harmonic $(2 \mathrm{X})$ describes 
the ovality (or elliptic shape) of rotor. As seen in Fig. 4, the eccentricity decreases for the upper end of rotor (Fig. 4a) and increases for its lower end (Fig. 4b). The ovality was the same before and after maintenance. The higher harmonics describe more complicated forms and are therefore a subject for future research. For example, the $12 \mathrm{X}$ harmonic shows that the rotor has 12 segments, but it is not clear yet what the changes in $12 \mathrm{X}$ denote. Also, it is not clear whether the $0.1 \div 0.2 \mathrm{~mm}$ increase or decrease in the $1 \mathrm{X}$ harmonic reveals an important change in the condition of generator. When the initial harmonic is $0.2 \mathrm{~mm}$, increase to $0.4 \mathrm{~mm}$ means the $50 \%$ increase. Such a high percentage of changes could be misleading, while in general the condition of the generator is acceptable (if using for evaluation the limit of $20 \%$ [12] and not of $8 \%$ [2]). In the future research the reference to the real-life values should be added to the spectrum.

The eccentricity or the ovality can reduce the operating efficiency and cause the magnetically-induced heating or a rotor-to-stator rub [1]. In our experiments the maintenance did not include balancing of the unit. Instead, the rotor windings of poles were repaired. This means that both the rotor poles and the guide bearings were dismounted and then assembled. Therefore, impairment of the eccentricity condition was possible.

Babic et.al. (2013) [16] used the spectrum analysis to show that the magnetic imbalance is characteristic of hydropower generator in the cases of large 1X harmonic of vibration spectrum. In the Limitations subsection, the vibration spectrum harmonics obtained in the case study are presented. Similar to [16], the $2 \mathrm{X}$ and $3 \mathrm{X}$ values obtained in the mentioned study were small, while the $1 \mathrm{X}$ value was relatively large. Yet, this is not enough to judge the magnetic imbalance condition, since the $1 \mathrm{X}$ value is normally the largest in vibration spectrum for hydrogenerator guide bearings. In revealing the numerical correlation of air gap values, the relationship between EMF and vibration remains the subject for future research.

\section{Limitations of the study}

From the fast-speed motor theory it follows that the analysis of generator air gap is a useful tool for eccentricity identification. In our study the vibration spectrum harmonic with $1 \mathrm{X}$ frequency represents the eccentricity [18]. Meanwhile, for slow-speed hydropower generators the general mechanical, electrical and hydraulic imbalance should be analysed based on the results of guide bearing vibration measurements, particularly for the $1 \mathrm{X}$ harmonic of vibration spectrum, with the results obtained in the runout mode preferred [1].

The vibration analysis carried out in our study shows that the $1 \mathrm{X}$ harmonic increased after maintenance. Although the increase is from $2 \mu \mathrm{m}$ to $6 \mu \mathrm{m}$ only, this is evidence that after maintenance the imbalance became greater. Table 4 summarises the information on the vibration of guide bearings before and after maintenance for a particular hydropower generation unit. The vibration sensor was mounted on a guide bearing casing in the radial direction. 
Changes in 1X harmonic of vibration spectrum for guide bearings in runout mode with rotational speed $95 \%$ of nominal

\begin{tabular}{|l|c|c|l|}
\hline Side of the unit & Vibration before, $\boldsymbol{\mu m}$ & Vibration after, $\boldsymbol{\mu m}$ & Change \\
\hline \multicolumn{4}{|c|}{ Guide bearing on generator } \\
\hline Left & 22 & 25 & Increase \\
\hline Front & 22 & 22 & - \\
\hline \multicolumn{4}{|c|}{ Guide bearing on turbine } \\
\hline Left & 8 & 14 & Increase \\
\hline Front & 10 & 12 & Increase \\
\hline
\end{tabular}

\section{Problems to be solved in further research}

The limitations of the study provided a definite guidance for future research. Some similarities in the spectra of air gap and stator core vibration at $100 \mathrm{~Hz}$ have already been found in this study. Indeed, the uneven air gap can cause the stator core to vibrate $[1,2]$. The causal air gap-vibration relationship is therefore one more subject of future investigation.

In addition, the pole temperature and the magnetic flux in the air gap are to be measured for accurate condition monitoring [14]. As noted in the Results and Discussion section, the air gap relation to electromagnetic force is also to be studied further.

\section{CONCLUSIONS}

Conclusions that can be drawn based on the results of study are as follows.

The method for measuring the generator air gap with contacting probes is relatively cheap, and can be evaluated by standard; at the same time, it is timeconsuming and prone to human errors.

An alternative technique - measuring with invasive sensors - is now commercially available, with evaluation metrics being developed by the manufacturers. The non-invasive techniques are still under development, while having a great potential. The results have shown that the measurements with invasive sensors provide almost the same precision as those with probes.

The pole diagram and spectrum analysis were successfully used to estimate the results of our case study. The air gap spectrum analysis has been proved to be a convenient evaluation tool; however, reliable criteria for the evaluation of air gap spectrum are still to be developed.

The study has shown that the results for air gap spectrum should be analysed together with the vibration monitoring data and vibration spectrum results for more accurate evaluation of hydropower generator condition.

\section{REFERENCES}

1. GE Energy (2005). Condition Monitoring Solutions for Hydro. Bently Nevada ${ }^{\mathrm{TM}}$. Asset Condition Monitoring. Available at http://www.ge-mcs.com/download/monitoring/ GEA13978_L.pdf_ 
2. STO 17330282.27.140.001-2006. Methods for Evaluating the Technical Condition of Major Hydroelectric Plant Equipment (in Russian: Стандарт ОАО РАО “Методики оценки технического состояния основного оборудования гидроэлектростанций”).

3. Babaei, M. Faiz, J., Ebrahimi, B.M., Amini, S., \& Nazarzadeh, J. (2011). A detailed analytical model of a salient-pole synchronous generator under dynamic eccentricity fault. Magnetics, IEEE Transactions on 47.4: 764-771.

4. Zuzin, A.F., Pokonov, N.Z., \& Antonov, M.V. (1971). Mounting, operation and maintenance of electrical equipment at manufacturing facilities. Москва: Высшая школа (in Russian: Зюзин А.Ф., Поконов Н.3. Антонов М.В. Монтаж, эксплуатация и ремонт электрооборудования промышленных предприятий и установок).

5. Air-gap measuring system LS 120 transducer and ILS 730 signal conditioner, Air-gap measuring systems manual, (C) Meggitt.

6. Chelvan, I. T. (2005). Non-Invasive Detection of Air gap Eccentricity in Synchronous Machines Using Current Signature Analysis. Thesis. Available in ProQuest Dissertation and Thesis database

7. Simond J.-J., Xuan M.T., Wetter R. (2008). An Innovative Inductive Air-Gap Monitoring for Large Low Speed Hydro-Generators, Proceedings of the International Conference on Electrical Machines

8. Rozenberg, G.Sh., Madorskij E.Z., \& Tadzhibaev A.I. (2003). Vibrodiagnostics. Saint Petersburg: PEIPK (in Russian: Г.Ш. Розенберг, Е.З.Мадорский, А.И. Таджибаев, Вибродиагностика, СПб.: ПЭИПК).

9. Al-Nuaimand, N. A., Toliyat, H. A. (1998). A novel method for modelling dynamic air gap eccentricity in salient pole synchronous machines based on modified winding function theory. IEEE Trans. Energy Conversion, 13 (2), 156-162.

10. Toliyat, H. A., \& Al-Nuaim, N. A. (1999). Simulation and detection of dynamic air-gap eccentricity in salient-pole synchronous machines. IEEE Trans. Industry Applications, 35 (1), 86-93.

11. Tabatabei, J., Faiz, H., \& Lesaniand, M. T. (2004). Modeling and simulation of a salientpole synchronous generator with dynamic eccentricity using modified winding function theory. IEEE Trans. Magnetics, 40 (3), 1550-1555.

12. VIBROSYSTM (2003). Mechanical Tolerance Guidelines for Hydroelectric Generators, application note AN001. Available at: www. vibrosystm.com

13. Elmanis-Helmanis, R., \& Griscenko, M. (2014). Study of Generator Modes Effects on Electric Power Quality and Air gap. RTUCON2014 Conference proceedings.

14. Air gap capacitive sensor (2014). Available at http://vibrosystm.com/wp-content/ uploads/9628-25D1A-102.pdf

15. De Silva, \& Clarence, W. (2000). Vibration: Fundamentals and Practice. CRC Press (USA).

16. Babic, B., Kartalovic, N., Marinkovic, S., Misovic, D., Teslic, D., Milosavljevic, Z., \& Nikolic, A. (2013). Correlations between Magnetic and Vibration Measurements on Hydro Generators. Recent Advances in Intelligent Control, Modelling and Simulation.

17. Timar P. L. (1989). Noise and Vibration of Electrical Machines. New York: Elsevier Science.

18. Urjev, E.V. (2003). Vibration and Balancing (lecture notes). Москва: Высшая школа (in Russian: Е.В. Урьев, Вибрация и балансировка: учебное пособие). 


\title{
HIDROĢENERATORA EKSCENTRICITĀTES ANALĪZE, IZMANTOJOT GAISA SPRAUGAS SPEKTRA REZULTĀTUS
}

\author{
M. Griščenko, R. Elmanis-Helmanis
}

K ops a vi $1 \mathrm{kums}$

Darbā aprakstīts piemērs hidroǵeneratora gaisa spraugas mērīšanai un novērtēšanai. Apskatīti trīs mērīšanas veidi, kā arī veikts eksperiments ar bezkontakta mērǐ̌sanas sistēmu. Iegūtie rezultāti novērtēti ar dažādām metodēm. Vispirms novērtējums veikts pēc gaisa spraugas maksimālām un vidējām vērtībām. Tad rotora forma novērtēta, attēlojot iegūtās vērtības uz apḷa diagrammas. Visbeidzot novērtēšana veikta ar spektrālanalīzes palīdzību. Spektrālanalīzes metodei vēl nav izstrādāti standarta novērtēšanas kritēriji, toties tā sniedz vairāk informācijas par iespējamo rotora ekscentricitāti un formu. Iepriekšējās autoru publikācijās spektrālanalīze jau tika ieteikta kā vēlamais nākamais solis rezultātu analīzē. Šajā darbā pirmo reizi parādīts, kā gaisa spraugas spektru var izmantot novērtěšanā turpmāko mērījumu laikā, papildinot grafisko analīzi.

19. 12.2014 . 